\title{
Lipids in cadaver sera after fatal heart attacks
}

\author{
J. B. ENTICKNAP \\ From East Ham Memorial Hospital, London
}

SYNOPSIS Blood lipids have been measured in sera from 750 cadavers. All nine fractions measured $\overrightarrow{\vec{\omega}}$ show a remarkably consistent pattern of differences between the various gross morbid anatomical $\stackrel{\circ}{\circ}$ forms of ischaemic heart disease. The highest mean values are found when an obvious coronary? thrombus is present and those in simple atheromatous occlusion are nearly as high. When there is $\overrightarrow{+}$ recognizable necrosis the values are considerably more normal. less.

The serum lipids show relatively little change due to autolysis, about one half of $1 \%$ per hour or

Lipoprotein levels assayed with $\mathrm{Cl}$.welchii alpha toxin correlate well with disease states.

Despite the precision of modern clinical diagnosis details of many morbid anatomical states can still only be ascertained at necropsy. Thus, in ischaemic heart disease, myocardial necrosis can confidently be predicted in a clinical attack but the presence or nature of arterial obstruction can only be inferred. In consequence, in most biochemical investigations, the label coronary thrombosis is used as a synonym but, whatever the frequency of minor mural thrombi, gross thrombi occluding the lumen are in fact relatively uncommon. This report describes consistent differences in the serum lipids between various morbid anatomical variants of the syndrome in a series of fatal cases. It also describes the effect of autolysis on the lipids, and contains data on the elegant method of Perrin (1959) for assessing lipoprotein with $\mathrm{Cl}$. welchii alpha toxin lecithinase.

$$
\text { MATERIAL AND METHODS }
$$

About 750 cadaver arm vein sera have been examined over four years (Enticknap, 1960a and b). About 200 were rejected because of infection or haemolysis. Most of the subjects had died unexpectedly and they are grouped by causes of death in Table I. Atherosclerosis was assessed in six sites giving an index up to a maximum of 24. No special techniques were used to discover small thrombi, the cases being diagnosed as coronary thrombosis or atheromatous occlusion depending on whether the lumen was occluded by ante-mortem clot obvious to the naked eye after multiple incisions.

TOTAL SERUM CHOLESTEROL This was estimated by a Liebermann-Burchard colour development technique using the rather large amount of $0.2 \mathrm{ml}$. sulphuric acid. The acid ferric chloride methods give very high blanks with cadaver sera.

TOTAL SERUM ESTERIFIED FATTY ACIDS The triolein standard of Stern and Shapiro (1953) was used. The $95 \%$ range of 104 normal blood donors was 5.7-12.3-18.9 $\mathrm{mEq} . / \mathrm{l}$. and there was no sex difference.

LIPOPROTEIN Perrin's (1959) technique was simplified:을 the change in opacity in 18 hours at $37^{\circ} \mathrm{C}$. of $0.3 \mathrm{ml} . \overrightarrow{\bar{O}}$ serum in $3 \mathrm{ml}$. Sorenson's borate buffer $p \mathrm{H} 7.61$ contain-3 ing $0.025 \mathrm{M} \mathrm{CaCl}_{2}$ and 0.8 Wellcome units of $\mathrm{Cl}$. Welchii alpha toxin (2 mg. of preparation $A G X 1552)$ in a $1 \mathrm{~cm} . \overline{0}$ cup at $650 \mathrm{~m} \mu$ was directly recorded. Electrophoresis allowed visual assessment of the fractions (Dangerfield? and Smith, 1955) and prebeta lipid was recorded in' Smith (1957) units. Beta-lipoprotein was also recorded by a modification of the original polysaccharide flocculation phenomenon of Bunstein and Samaille (1956); the opacity developed by $0.2 \mathrm{ml}$. serum in $2.0 \mathrm{ml}$. of 0.060 $\mathrm{M} \mathrm{CaCl}_{2}$ on treatment with $0.04 \mathrm{ml} .1 \%$ calcium heparin was referred to Kunkel's (1947) barium sulphate standard, and assigned a value of 10 units with an Ilford 609 filter. The $95 \%$ range of 104 normal blood donors was $3.0-N$ $9 \cdot 6-16.1$ units and the original data suggest that oneunit is about $0.4 \mathrm{~g}$.

\section{RESULTS}

There are slight changes in some of the lipid values with time elapsing between death and necropsy? (Table II). They show a diphasic pattern of accumulation in the serum around a skew rising mean with ao declivity at around the end of the second day. In disease groups which were large enough to giveri 
TABLE I

CLASSIFICATION BY CAUSES OF DEATH AND DISTRIBUTION OF SERUM LIPIDS

\begin{tabular}{|c|c|c|c|c|c|c|c|c|}
\hline & \multicolumn{5}{|c|}{ Ischaemic Heart Disease } & \multirow{2}{*}{$\begin{array}{l}\text { Other } \\
\text { Forms of } \\
\text { Heart } \\
\text { Disease }\end{array}$} & \multirow{2}{*}{$\begin{array}{l}\text { Other } \\
\text { Forms of } \\
\text { Arterial } \\
\text { Disease }\end{array}$} & \multirow{2}{*}{$\begin{array}{l}\text { Control } \\
\text { Cases }\end{array}$} \\
\hline & $\begin{array}{l}\text { Coronary } \\
\text { Occlusion } \\
\text { by Atheroma }\end{array}$ & $\begin{array}{l}\text { Myocardial } \\
\text { Fibrosis }\end{array}$ & $\begin{array}{l}\text { Myocardial } \\
\text { Necrosis }\end{array}$ & $\begin{array}{l}\text { Coronary } \\
\text { Thrombosis }\end{array}$ & All Cases & & & \\
\hline $\begin{array}{l}\text { Average age in years } \\
\text { Proportion of males to females } \\
\text { Index of atherosclerosis }\end{array}$ & $\begin{array}{c}62 \\
12\end{array}$ & $\begin{array}{c}74 \\
0 \cdot 8 \\
12\end{array}$ & $\begin{array}{c}69 \\
0.9 \\
14\end{array}$ & $\begin{array}{l}68 \\
13\end{array}$ & $\begin{array}{c}66 \\
1 \cdot 2 \\
13\end{array}$ & $\begin{array}{l}68 \\
1 \cdot 9 \\
8\end{array}$ & $\begin{array}{l}69 \\
0 \cdot 5 \\
10\end{array}$ & $\begin{array}{l}62 \\
0.9 \\
6\end{array}$ \\
\hline $\begin{array}{l}\text { Total serum cholesterol } \\
\text { Mean value (mg./100 ml.) } \\
\text { Standard deviation } \\
\text { Number of observations }\end{array}$ & $\begin{array}{r}262 \\
83 \\
17\end{array}$ & $\begin{array}{r}251 \\
65 \\
15\end{array}$ & $\begin{array}{r}205 \\
78 \\
15\end{array}$ & $\begin{array}{r}306 \\
85 \\
7\end{array}$ & $\begin{array}{r}260 \\
83 \\
54\end{array}$ & $\begin{array}{r}197 \\
78 \\
11\end{array}$ & $\begin{array}{r}231 \\
90 \\
14\end{array}$ & $\begin{array}{r}175 \\
71 \\
46\end{array}$ \\
\hline $\begin{array}{l}\text { Total serum fatty acids } \\
\text { Mean value (mEq./l.) } \\
\text { Standard deviation } \\
\text { Number of observations }\end{array}$ & $\begin{array}{c}19 \cdot 3 \\
8 \cdot 4 \\
71\end{array}$ & $\begin{array}{c}13 \cdot 7 \\
3 \cdot 9 \\
13\end{array}$ & $\begin{array}{r}15 \cdot 1 \\
5 \cdot 7 \\
41\end{array}$ & $\begin{array}{l}15 \cdot 5 \\
5 \cdot 0 \\
27\end{array}$ & $\begin{array}{r}15 \cdot 7 \\
7 \cdot 1 \\
152\end{array}$ & $\begin{array}{c}11 \cdot 9 \\
4 \cdot 3 \\
25\end{array}$ & $\begin{array}{l}15 \cdot 9 \\
9 \cdot 2 \\
55\end{array}$ & $\begin{array}{r}12 \cdot 9 \\
5 \cdot 0 \\
85\end{array}$ \\
\hline Total lipoprotein & & & & & & & & \\
\hline Mean values (alpha toxin $\left.\mathrm{dE}_{1 \mathrm{~cm} .}^{650}\right)$ & 0.53 & 0.45 & $0 \cdot 35$ & 0.54 & 0.47 & $0 \cdot 28$ & 0.45 & $0 \cdot 30$ \\
\hline $\begin{array}{l}\text { Standard deviation } \\
\text { Number of observations }\end{array}$ & $39 \cdot 27$ & $\begin{array}{l}0 \cdot 40 \\
7\end{array}$ & $\begin{array}{c}0 \cdot 32 \\
21\end{array}$ & $\begin{array}{l}0 \cdot 24 \\
18\end{array}$ & $8^{0.35}$ & 20 & $0 \cdot 33$ & $\begin{array}{l}0 \cdot 18 \\
43\end{array}$ \\
\hline $\begin{array}{l}\text { Beta lipoprotein } \\
\text { Mean value (heparin units) } \\
\text { Standard deviation } \\
\text { Number of observations } \\
\text { Mean value (electrophoretic units) } \\
\text { Standard deviation } \\
\text { Number of observations } \\
\text { Mean value (Smith units of pre- } \\
\text { beta lipid) } \\
\text { Standard deviation }\end{array}$ & $\begin{array}{l}16.9 \\
6.0 \\
12 \\
1.4 \\
0.48 \\
71 \\
\\
2.0 \\
1.61\end{array}$ & $\begin{array}{l}14 \cdot 1 \\
4 \cdot 5 \\
7 \\
1.0 \\
1.0 \\
11 \\
\\
1.6 \\
1.82\end{array}$ & $\begin{array}{l}14 \cdot 1 \\
6 \cdot 9 \\
8 \\
1 \cdot 4 \\
0 \cdot 73 \\
38 \\
\\
2.3 \\
1.64\end{array}$ & $\begin{array}{l}22 \cdot 7 \\
2 \cdot 5 \\
3 \\
1 \cdot 6 \\
0.6 \\
23 \\
\\
3 \cdot 1 \\
1.94\end{array}$ & $\begin{array}{c}16 \cdot 1 \\
6 \cdot 5 \\
30 \\
1 \cdot 4 \\
0 \cdot 74 \\
143 \\
\\
2 \cdot 2 \\
2 \cdot 24\end{array}$ & $\begin{array}{l}11.8 \\
7.0 \\
8 \\
1.0 \\
0.85 \\
17 \\
\\
1.4 \\
1.58\end{array}$ & $\begin{array}{c}15 \cdot 3 \\
7 \cdot 5 \\
7 \\
1 \cdot 0 \\
0 \cdot 68 \\
27 \\
\\
1 \cdot 5 \\
1 \cdot 41\end{array}$ & $\begin{array}{c}11 \cdot 0 \\
5.7 \\
35 \\
1 \cdot 1 \\
0.77 \\
92 \\
\\
1 \cdot 2 \\
1.55\end{array}$ \\
\hline $\begin{array}{l}\text { Alpha/beta ratio } \\
\text { Mean value (normal }=1.0 \text { ) }\end{array}$ & 0.41 & 0.54 & 0.65 & $0 \cdot 35$ & 0.47 & 0.81 & 0.64 & 0.67 \\
\hline $\begin{array}{l}\text { Alpha lipoprotein } \\
\text { Mean value in electrophoretic units } \\
\text { Mean opacity of serum diluted }\end{array}$ & 0.7 & $0 \cdot 5$ & 0.8 & $0 \cdot 7$ & $0 \cdot 7$ & $0 \cdot 7$ & 0.8 & 0.7 \\
\hline $1: 10$ in borate buffer $\left(E_{650}^{1 \mathrm{~cm} .}\right)$ & $0 \cdot 23$ & $0 \cdot 19$ & $0 \cdot 19$ & $0 \cdot 18$ & $0 \cdot 21$ & $0 \cdot 20$ & $0 \cdot 19$ & $0 \cdot 16$ \\
\hline
\end{tabular}

TABLE II

CHANGES IN BLOOD LIPIDS WITH INCREASING INTERVALS BETWEEN DEATH AND NECROPSY

\begin{tabular}{lcccccc}
$\begin{array}{l}0-12 \\
\text { Hours }\end{array}$ & $\begin{array}{l}13-24 \\
\text { Hours }\end{array}$ & $\begin{array}{l}25-36 \\
\text { Hours }\end{array}$ & $\begin{array}{l}37-48 \\
\text { Hours }\end{array}$ & $\begin{array}{l}49-60 \\
\text { Hours }\end{array}$ & $\begin{array}{l}\text { More than } \\
60 \text { Hours }\end{array}$ & $\begin{array}{l}\text { Mean } \\
\text { Hourly } \\
\text { Increment }\end{array}$ \\
\hline 195 & 207 & 213 & 232 & 200 & 215 & 0.5 \\
11.8 & 13.2 & 13.4 & 15.8 & 11.2 & 13.6 & 0.04 \\
8.3 & 11.3 & 13.5 & 8.5 & 15.0 & 14.9 & 0.1 \\
0.9 & 1.2 & 1.4 & 1.2 & 1.4 & 1.4 & 0.01 \\
1.1 & 1.8 & 2.0 & 1.8 & 2.1 & 2.1 & 0.01 \\
0.49 & 0.35 & 0.37 & 0.50 & 0.35 & 0.40 & - \\
0.8 & 0.5 & 0.8 & 0.5 & 0.5 & 0.7 & - \\
0.6 & 0.7 & 0.8 & 0.7 & 0.8 & 0.7 & - \\
1.2 & 1.2 & 1.3 & 1.2 & 1.2 & 1.3 & - \\
0.05 & 0.18 & 0.30 & 0.18 & 0.16 & 0.12 & -
\end{tabular}

Cholesterol (mg. per $100 \mathrm{ml}$.)

Mean value for all sera tested

Total fatty acids (mEq./1.)

Beta lipoprotein

(a) heparin units

(b) Sudan black units after electrophoresis

(c) Prebeta lipid in Smith units

Lipoprotein (Perrin) ( $\left.\begin{array}{c}\mathrm{dE} 1 \mathrm{~cm} . \\ 650\end{array}\right)$

Alpha/beta lipoprotein ratio (normal $=1$ )

Alpha lipoprotein

Gamma globulin

Serum opacity

normal = 1)

informative means the pattern was similar. A mean hourly increment was calculated from lines of best fit. The disease groups were all of comparable mean age and the necropsies were performed at fairly uniform mean time intervals.

The mean values of the serum lipids have been 
grouped (Table I) to show the changes attributable to ischaemic heart disease, its four morbid anatomical variants of simple atheromatous coronary occlusion, myocardial fibrosis, myocardial necrosis, and coronary thrombosis, and to enable the effects of arterial disease not primarily affecting the heart (systemic atherosclerosis) and heart disease not due to vascular occlusion to be assessed. All other causes of death formed the control group, with the exception of cancer which caused uniformly low lipid values and so was excluded. This control group was analysed into six components but no consistent differences were seen.

There was a close correlation between the serum fatty acid content and lipoprotein measured by lecithinase with lipaemia assessed both with the naked eye and photometrically (Fig. 1). Eight out of 10 milky sera occurred in ischaemic heart disease. Numerous calculations show that haemolysis does not regularly affect the various lipid fractions of

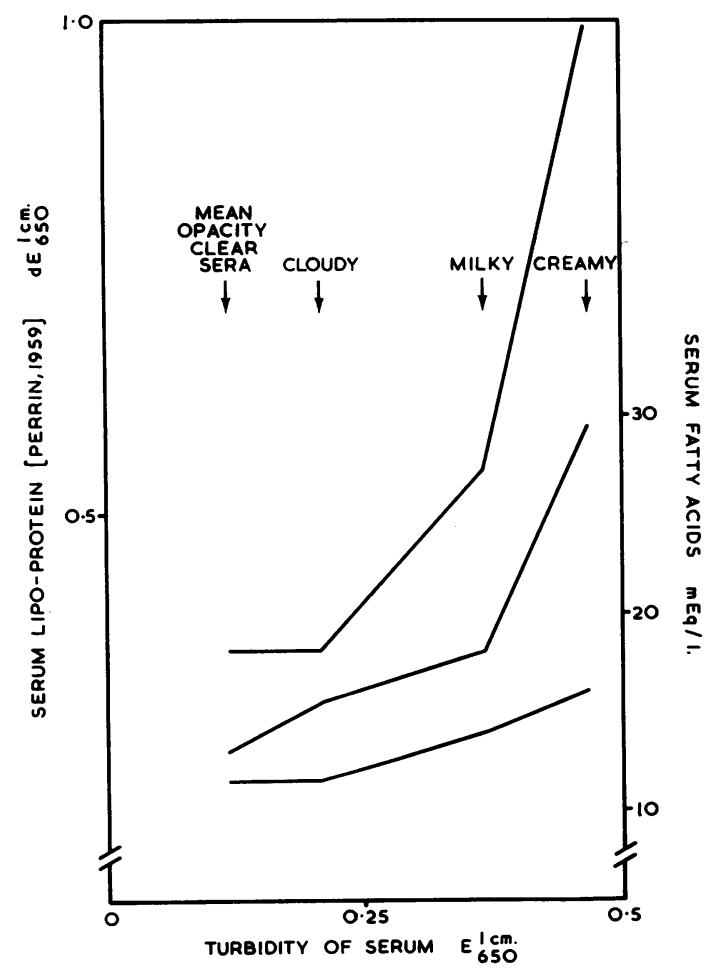

FIG. 1. The relationship between serum turbidity and its content of lipoprotein and fatty acids. The four points represent groups of sera considered visually to be comparable. In the top line the mean opacity of groups of cadaver sera is plotted against lipoprotein content (Perrin, 1959), in the second line against the mean fatty acid content of these same groups, and in the third line against the mean fatty acid content of groups of blood donor sera. cadaver sera nor do they correlate with the index of $\underset{\vec{A}}{\vec{A}}$ atherosclerosis at all closely. There was no consistent relationship with the state of the stomach contents and, compared with the controls, there was no significantly greater frequency of recent ingestion in the subjects with ischaemic heart disease. There is a $\varrho$ significant, but not close, correlation between the \& individual values of fatty acids and alpha-toxin units $\overrightarrow{0}$ of lipoprotein in 200 sera $(r=0.33$; s.e. 0.071$)$.

\section{DISCUSSION}

These four semantic variants of ischaemic heart $\vec{A}$ disease are commonly used on death certificates ir despite the overlap between their morbid anatomical $\overrightarrow{0}$ counterparts. Their proportions of approximately

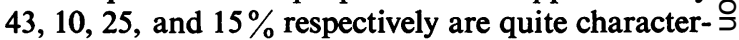
istic of the more sudden seizures. This investigation $\vec{c}$ was begun to elucidate those cases, here referred to $\mathbb{D}$ as coronary occlusion, in which death was un- $\frac{\vec{D}}{\mathbb{D}}$ doubtedly due to acute cardiac ischaemia but in 3 which careful post-mortem dissection does not reveal $\mathbb{D}$ any recent gross changes in myocardium or arteries. As they show no obvious thrombotic occlusion and, $\mathscr{\circ}$ indeed, unless special techniques are used, no.thrombi at all, the mechanism of death is obscure. Enzyme assays are consistent with the absence of necrosis in these cases (Enticknap, 1960b). This investigation shows abnormalities of their serum lipids which present rather more clear differences than those $\stackrel{\mathbb{Q}}{\mathscr{Q}}$ found when necrosis is established. Further, it $\vec{\overrightarrow{ }}$ demonstrates that while the most abnormal lipids 3 are found in those cases with an obvious thrombus, $\bar{F}$ the cases of occlusion resemble them fairly closely.

Autolytic changes must be considered. Laves (1960) has shown that the ultra-violet absorption? spectrum of the blood is changing even within the $\frac{0}{3}$ moments before death. Other substances, particularly: serum enzymes, also change with extreme rapidityo (Enticknap, 1960b) and rise to very high levels. Serum lipids, on the other hand, although showing? qualitatively similar changes, are quantitatively much $D$ less altered, and corrections based on the increments in Table II do not affect the argument. In 1936, N Landé and Sperry, at Schonheimer's suggestion (Sperry, 1957), made post-mortem cholesterol analyses and Faber (1946) considered that any differences hew encountered in serial estimations were within the limits of experimental error. More recently Patersono and Dyer (1959) have measured ante- and post $-\overline{\mathbb{W}}$ mortem cholesterol analyses in a closed population? and concluded that they were comparable, provided that death was sudden, and Glanville (1960) has reported on hospital subjects. Schlang and Davis卫 (1958), Schleyer (1954), and Spain, Bradess, an $\$$ Greenblatt (1954) have all reported satisfactoryo 
separations of cadaver serum proteins. It appears legitimate, therefore, directly to correlate lipid analyses on cadaver sera with disease states.

While the level of total esterified fatty acids appears to be the most useful test in confirming a necropsy diagnosis of simple coronary occlusion as a cause of death, the other fractions all appear to be of about equal value. Perrin's technique for total lipoprotein yields results with a fairly wide spread of differences between the syndromes and also gives very high values in the puzzling cases of occlusion, but the discrimination between the various groups is insufficiently good to justify the routine use of this rather complex method. He shows that it correlates with phospholipids in his Fig. 1 but no coefficient is given. In this series a loose relationship with total esterified fatty acids is shown but the technique clearly does not simply measure this parameter.

The lipids are most raised in the ischaemic heart disease group and moderately raised in the systemic atherosclerosis group, and many of the differences attain conventional significance $(p<0 \cdot 05)$. Thus ischaemic heart disease has a significantly higher mean cholesterol level than heart disease not due to vascular occlusion (standard error of difference $25 \mathrm{mg} . / 100 \mathrm{ml}$.) and than the control group (s.e. diff: 15), but not than systemic atherosclerosis (s.e. diff: 27). Heart disease not due to vascular occlusion, on the other hand, closely resembles the controls, there being in fact no significant differences (s.e. diff; for pre-beta lipid: 0.34). Beta-lipoprotein and pre-beta lipid also differ significantly in the ischaemic heart disease and systemic atherosclerosis groups (s.e. diff: $0 \cdot 147$ and 0.103). Data from 13 of the cases of Landé and Sperry (1936) and from 28 of Faber's (1946) cases can also be arranged to compare these groups and show a similar small mean cholesterol difference to that reported here $(31,28$, and $29 \mathrm{mg}$. per $100 \mathrm{ml}$. respectively).

The differences between the various forms of ischaemic heart disease are, however, more interesting and cannot be determined in clinical cases. The lipids in myocardial fibrosis, in which the heart failure is less sudden, are among the lowest recorded in fatal atherosclerosis and closely resemble those of non-cardiac arterial disease, there being no significant differences in this series. The mean fatty acid level is significantly lower than in coronary occlusion (s.e. diff: 1.66) and most of the other values differ markedly from those found when a thrombus is present.

Coronary thrombosis, on the other hand, is associated with the most abnormal pattern. Betalipoprotein is significantly greater than in any other group (s.e. diff. from coronary occlusion; $2 \cdot 25$ ) and so is pre-beta lipid (s.e. diff. from myocardial necrosis $0 \cdot 22$ ). This is in fact the biggest mean increase of any fraction, being more than 2.5 times that of the control group mean. The mean cholesterol level (s.e. difference 38), total lipoprotein (s.e. diff. 0.04 ), and the alpha-beta ratio all differ significantly from those of myocardial necrosis although not from those of the rest of the group. Thus the cases of myocardial necrosis have a significantly lower cholesterol, total lipoprotein, beta lipoprotein, and pre-beta lipid, and higher alpha-beta ratio than cases in which a thrombus was present.

The cases of coronary occlusion by uncomplicated atheroma share the highest mean levels with the thrombotic cases. Significant differences are seen only in beta lipoprotein and in pre-beta lipid but the serum fatty acids are higher in this class than in any other. Apart from this all the other most abnormally raised mean values occurred in the group of cases of coronary thrombosis (italics in Table I).

Two conclusions emerge. First, when cases of fatal ischaemic heart disease are grouped by conventional naked-eye necropsy criteria consistent differences are observed in the levels of the serum lipids. This fact is consistent with the hypothesis that the causes of death certified may have different mechanisms. Secondly, stoppage of the heart when the myocardium is apparently normal or when necrosis is minimal occurs when the blood lipids are most markedly abnormal. The more abnormal they are the more likely is a large thrombus to be present; established necrosis, on the other hand, is found when the lipids are much less abnormal. In any event the similarity between the findings in simple and thrombotic occlusion is confirmatory evidence that the former may indeed cause death when there is no evidence of gross recent thrombotic or necrotic change.

\section{REFERENCES}

Bunstein, M., and Samaille, J. (1956). C.R. Acad. Sci. (Paris), 243, 2185 .

Dangerfield, W. G., and Smith, E. B. (1955). J. clin. Path., 8, 132.

Enticknap, J. B. (1960a). Lancet, 1, 32.

(1960b). J. forensic Med. 7, 135.

Faber, M. (1946). Acta med. scand., 125, 418.

Glanville, J. N. (1960). Brit. med. J., 2, 1852.

Kunkel, H. G. (1947). Proc. Soc. exp. Biol. (N.Y.), 66, 217.

Landé, K. E., and Sperry, W. M. (1936). Arch. Path. (Chicago), 22, 301.

Laves, W. (1960). J. forensic Med., 7, 70.

Paterson, J. C., and Dyer, L. (1959). Circulation, 20, 989.

Perrin, J. (1959). J. clin. Path., 12, 459.

Schlang, H. A., and Davis, D. R. (1958). Amer. J. med. Sci., 236, 472. Schleyer, F. (1954). Naunyn-Schmiedeberg's Arch. exp. Path. Pharmak., $221,306$.

Smith, E. B. (1957). Lancet, 2, 910.

Spain, D. M., Bradess, V. A., and Greenblatt, I. J. (1954). J. Amer. med. Ass., 156, 246.

Sperry, W. M. (1957). In Chemistry of Lipides as Related to Atherosclerosis, A Symposium, ed. I. H. Page, p. 260. Thomas, Springfield, Illinois.

Stern, I., and Shapiro, B. (1953). J. clin. Path., 6, 158. 